\title{
HOW DOES IT WORK? \\ SUPPORTING THE DEVELOPMENT OF TECHNICAL THINKING OF PRIMARY AND SECONDARY SCHOOL PUPILS
}

\author{
Anna ŠMERINGAIOV $\boldsymbol{A}^{*}$, Technická univerzita v Košiciach, Slovenská \\ republika
}

Přijato: 23. 11. 2019 / Akceptováno: 31. 3. 2020

Typ článku: Teoretická studie

DOI: $10.5507 /$ jtie.2020.004

Abstract: The article is devoted to the development of technical literate society of the 21 st century in the context of securing a professionally skilled workforce in promising areas of industry. It is necessary to lay the foundations of technical literacy at pre-school age and to continue throughout all life. In building a relationship to technology, it is necessary to encourage the internal motivation of children, which is based on natural curiosity and the need to know. In addition to teaching technology at primary and secondary levels of primary school, a number of secondary technical and technical colleges, state institutions and the media have an important support role in technical education for children. The following are examples of activities aimed at popularizing science and technology in Slovakia.

Key words: technical literacy, education, popularization, science, technology.

\section{JAK VĚCI FUNGUJÍ? PODPORA ROZVOJE TECHNICKÉHO MYŠLENÍ U ŽÁKU ZÁKLADNÍCH ŠKOL}

Abstrakt: Článek je věnován otázkám rozvoje technicky gramotné společnosti 21. století v kontextu zajištěni odborně zdatné pracovní sily v perspektivnich oblastech prưmyslu. Základy technické gramotnosti je nutné položit už $v$ predškolním věku a pokračovat celý život. Při budování vztahu $k$ technice je nutné povzbudit vnitřní motivaci dětí, která je postavena na přirozené zvědavosti a potrebě poznávat. Vedle výuky techniky na primárním a sekundárním stupni základní školy, má v oblasti technického vzdělávání dètí významnou podpornou roli celá řada aktivit střednich a vysokých škol technického zaměrení, státnich institucí a médii. Uvedené jsou př́klady aktivit zaměrených na popularizaci vědy a techniky na Slovensku.

Klíčová slova: technická gramotnost, vzdělávání, popularizace, věda, technika.

*Autor pro korespondenci: anna.smeringaiova@tuke.sk 


\section{1 Úvod}

Pravděpodobně ještě nikdy $\mathrm{v}$ historii samostatné Slovenské republiky nebyla na pracovním trhu poptávka po absolventech technických oborů v takovém rozsahu, jako dnes. Na Slovensku pozorujeme zajímavý trend. Populační křivka klesá, ale počet vysokých škol roste. Paleta možností výběru odborného zaměření studia je široká. Převládá zájem o studium humanitních oborů. Technické univerzity jsou nuceny $\mathrm{v}$ tomto konkurenčním prostředí studenty zaujmout, získat a udržet si je. Potenciální studenty je zapotřebí hledat již v řadách nejmladší generace. Zájem o studium techniky na středních a vysokých školách je proto nutné rozvíjet a podporovat už u žákủ základních a mateřských škol. V tomto kontextu je důležité volit vhodné metody a formy rozvoje technické gramotnosti, technické tvořivosti a technického myšlení odpovídající věku a mentální vyspělosti dětí. Vedle výuky techniky na primárním a sekundárním stupni základní školy, má v oblasti technického vzdělávání dětí významnou podpornou roli celá řada aktivit středních a vysokých škol technického zaměření, státních institucí a médií.

\section{Použité metody}

Při zpracovávání studie byly využity především teoretické metody, které spočívaly ve studiu publikovaných vědeckých statí, výzkumných zpráv a strategických vládních dokumentů. Získané poznatky byly podrobeny komparativní analýze a hodnocení s cílem uspořádat je do vzájemných souvislostí. Popsány byly problémy spojené s fenomény, které se aktuálně vyskytují ve společnosti, resp. vzdělávací teorii i praxi. Naznačeny byly možné přistupy k řešení nastolených problémů obecně i na konkrétních př́kladech. Aplikován byl analyticko-syntetický přístup, cílem kterého bylo porozumění a popsání vztahů a principů platných v procese vzdělávání, zejména se zaměřením na technické vzdělávání předškolních dětí a žáku základních škol.

\section{Vymezení pojmu technická gramotnost}

Technickou gramotnost definuje R. A. Dixon (2013) jako zásadní formu gramotnosti pro 21. století, srovnatelnou s matematickou, přírodovědnou, informační nebo čtenářskou gramotností. Pojem technická gramotnost je vymezen jako schopnost používat, řídit, hodnotit a pochopit technologie. Autoři J. Kropáč (2004) a J. Stoffa (1992) nahlížejí na technickou gramotnost jako na soubor těchto schopností: uvědomovat si klíčové procesy $\mathrm{v}$ technice (co to je a jak to funguje), umět obsluhovat technické přístroje a zařízení, umět aplikovat technické poznatky $\mathrm{v}$ nových situacích, neustále rozvíjet vlastní technické vědomosti, dovednosti a návyky, umět využívat technické informace a hodnotit je. Pod pojem technická gramotnost je možné zahrnout i oblast emotivní - schopnost ovládat a rozvíjet emoce při činnosti s technikou anebo v situacích, do kterých technika vstupuje.

\section{Koncept STEM a trvale udržitelný rozvoj společnosti}

Koncept STEM vznikl v USA v 90. letech minulého století. Písmena v názvu označují princip vzdělávání ve vzájemně propojených oborech přírodní vědy (Science), techniky (Technology) a technologie (Engineering) a matematiky (Matematics).

Koncept STEM je možné vymezit hesly:

- $\quad$ STEM jako reakce na nové společenské potřeby.

- $\quad$ STEM jako integrační tendence ve vzdělávání. 
Podle autorů J. Dostál a V. Prachagool (2016) „STEM predstavuje prostor, ve kterém se setkávají různé zájmy - zájmy společnosti, úradư, škol, profesnich organizací, jedinců a podnikü, které jsou nasměrovány $k$ růstu společnosti jako celku a zachováni jeho ekonomické stability."

Zřetelná je orientace na vzdělávání, které je vnímáno jako podstatný faktor. Hlavním smyslem tohoto konceptu je príprava absolventů stávajících i nově vznikajících technických oborů a zajištění pracovní síly v perspektivních oblastech průmyslu. Jak bylo zmíněno, vztah $\mathrm{k}$ technice je nutné začít budovat již u dětí předškolního věku. Vzdělávání formou hry je nejlepší metoda, jak děti nenásilně zapojit do učení. Četné aktivity institucí, médií, středních a vysokých škol technického zaměření v oblasti popularizace vědy a techniky vytvářejí pestrou paletu možností rozvíjení jejich technické tvořivosti a technického myšlení.

\section{Aktivity vzdělávacích institucí a médií v oblasti technického vzdělávání}

Jedním ze základních východisek "Strategie slovenské republiky pro mládež na období 2014 - 2020" je iniciativa EU "Mládež v pohybu", která je součástí strategie Evropa 2020. Cílem této iniciativy je posunout mladé lidi do centra pozornosti agendy EU, aby vytvořili hospodářství založené na znalostech, inovaci, vysoké míre vzdělanosti a dovedností, přizpůsobivosti a kreativitě, inkluzivních trzích práce a aktivním zapojení do společnosti.

Technikou je dnes prostoupena celá společnost, náš každodenní běžný i profesní život. Výchova technicky gramotné společnosti 21. století už není jenom záležitostí škol. Základy technické gramotnosti je nutné položit už v předškolním věku a pokračovat celý život (Turek, 2011). Podpora technického vzdělávání nejmladší generace mimo základního vzdělávacího systému probíhá uplatněním celé řady aktivit. Jejich iniciátorem jsou státní i soukromé instituce, média, vysoké a střední školy. Pořádané jsou přednášky, výstavy a workshopy zaměřené na seznámení $\mathrm{s}$ technikou. Přinášejí informace $\mathrm{z}$ různých technických oborů. Možnosti hlubšího seznámení s technikou dětem nabízejí centra volného času. $V$ široké nabídce kurzů si děti vyzkouší celou řadu technicky zaměřených aplikací, činností či zařízení.

Národní centrum pro popularizaci vědy a techniky ve společnosti zastř̌šuje aktivity zaměřené na popularizaci vědy a techniky na Slovensku. Už od roku 2007, kdy bylo zř́zeno, realizuje množství aktivit, podporuje komunikaci vědeckých informací prostřednictvím webových stránek a spolupracuje s médii s cílem informovat co nejšisší veřejnost o výsledcích slovenského výzkumu a vývoje. Je organizátorem a spoluorganizátorem mnoha zajímavých aktivit. Svou pozornost věnuje všem cílovým skupinám. Na akcích, jako Noc výzkumníků, Týden vědy a techniky, Festival vědeckých filmů nebo Vědecká kavárna si každý najde to, co ho zajímá. Stejně aktivity a expozice technických muzeí, vědeckých knihoven jsou často využívány jako doplňková forma výuky na základních a středních školách. (NCP VaT, 2019)

Televize, rozhlas, odborné časopisy prrispívají také k popularizaci technických oborů. Mezi nejpopulárnější patří pořady Svět technologií, Bořiči mýtů, Lovci záhad, Hyde park Civilizace, Úžasná tajemství vědy, Dobrodružství vědy a techniky, Horizont, nebo magazín o vědě a technice Quark. $Z$ výsledků výzkumu sledovanosti vědeckých pořadů (Špaček, 2015) vyplývá, že populárně vědecké pořady sleduje v televizi $35 \%$ 
dotazovaných a na internetu 35,7 \% dotazovaných. Zároveň ale 52, $5 \%$ respondentů se domnívá, že je těchto popularizačních pořadů málo.

Ze strany středních a vysokých škol se můžeme setkat s mnoha akcemi zaměřenými na popularizaci techniky a v neposlední řade oslovení potencionálních studentů. Každý rok školy organizují „,Den otevřených dveří“. Pro všechny návštěvníky jsou připravené různé výstavy, workshopy a jiné aktivity. Velmi oblíbené jsou „Dětské univerzity“, kde mají žáci základních škol možnost seznámit se nejen s univerzitním prostředím, ale i se spoustou zajímavých činností, mezi které patří i činnosti technicky zaměřené. Dále je popsáno několik př́ikladů popularizačních a vzdělávacích aktivit, které organizovala, resp. na kterých se spolupodílela Fakulta výrobních technologií Technické univerzity v Košicích.

\subsection{Den otevrených dveři}

Všechny fakulty Technické univerzity $\mathrm{v}$ Košicích každoročně pořádají "Den otevřených dveří". Účastní se ho především studenti středních škol, kteří se rozhodují, kam na vysokou školu. Každý rok je zájem také ze strany základních škol. Otevřené jsou všechny studovny a laboratoře. Připravené jsou hry, soutěže a ukázky výsledků práce studentů Technické univerzity i pracovníků výzkumu. Programová náplň projektů se vybírá tak, aby podnítila účastníky „Dne otevrených dveři“ aktivně se zapojovat do všech prezentovaných činností.
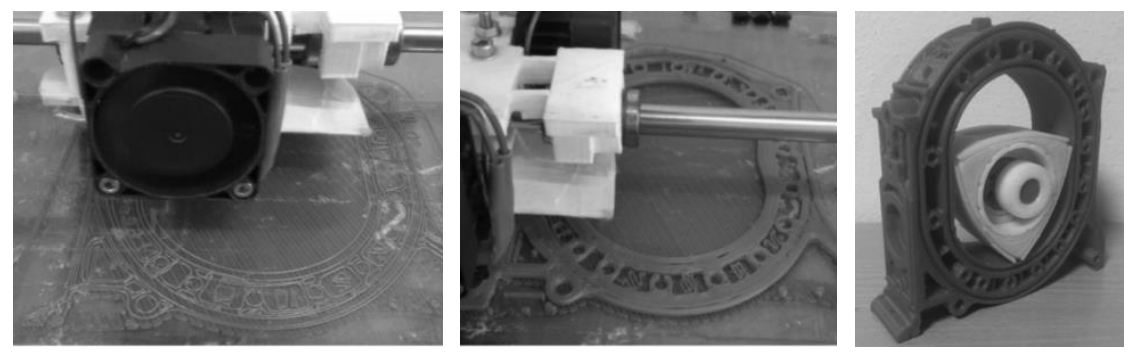

Obr. č. 1: Wankelưv motor - 3D tisk a 3D model pro simulaci pohybu (Kmeč, 2017).

\subsection{Dětská univerzita na TUKE}

První ročník „Dětské univerzity na TUKE“ se uskutečnil v roce 2006 . V roce 2019 se uskutečnil již 14. ročník s názvem „Jsme TU pro děti“ Na př́ípravě dětské univerzity na Technické univerzitě v Košicích se podílejí všechny její fakulty. Témata přednášek vycházejí z odborného zaměření pedagogů, ale jsou přizpůsobeny věku a zájmům dětí. V Tab. č. 1 je uvedeno několik př́íkladů přednášených témat. Různá odborná témata jsou dětem vysvětlena zábavnou formou s přihlédnutím na úroveň jejich znalostí. Cílenými praktickými ukázkami se animátoři snaží podchytit zájem žáků o poznávání a řešení technických problémů a činností. Dětem je prezentovaná vzájemná propojenost poznatků z prírodních věd, techniky, informatiky a matematiky. Zkušenost dokazuje, že i když se jednalo o technická témata, děti reagovaly se zájmem, spontánně a menší zájem nebyl prokázaný ani u žáků inklinujících $\mathrm{k}$ humanitním předmětům. 


\begin{tabular}{|l|l|}
\hline \multicolumn{1}{|c|}{ Fakulta } & \multicolumn{1}{c|}{ Téma přednášky } \\
\hline$F E I$ & Pestrý svět robotů. \\
\hline$S j F$ & Úžasný svět mechaniky. \\
\hline$F V T$ & Poznávej svět rožšírenou realitou. \\
\hline$F M M R$ & Jak se vyrábí materiál pro výrobu věcí kolem nás? \\
\hline$S v F$ & Kreativní stavitel - z čeho všeho se dá postavit dům? \\
\hline
\end{tabular}

Tab. č. 1: Výběr z přednášených témat (Dětská univerzita TUKE, 2019).

\subsection{Centrum edukace a popularizace techniky (CEPT)}

Kolektivy FHPV PU v Prešově, pod vedením prof. J. Pavelku a KNMTS FVT v Prešově, TU v Košicích, pod vedením prof. S. Pavlenka se podíleli na společném projektu - vytvoření "Centra edukace a popularizace techniky" (CEPT, 2019). CEPT bylo zř́zeno v prostorách katedry fyziky, matematiky a techniky FHPV PU v Prešově. Pilotní provoz byl spuštěn v březnu 2017. Cílem vývojově-edukačního pracoviště popularizace vědecko-technických poznatků bylo hledat a ověrit cesty ke zvýšení zájmu žáků základních škol o techniku, rozvíjení jejich technického myšlení, budování vztahu $\mathrm{k}$ technice a ke studiu oborů $\mathrm{s}$ technickým zaměřením. Vytvořené byly dva učební prostory s tematicky uspořádanými pracovišti: Demonstrativni laboratoř odborných predmétů (Obr. č. 2) a Specializované učebny strojnich technologii obráběni dřeva, kovĩ a plastü.

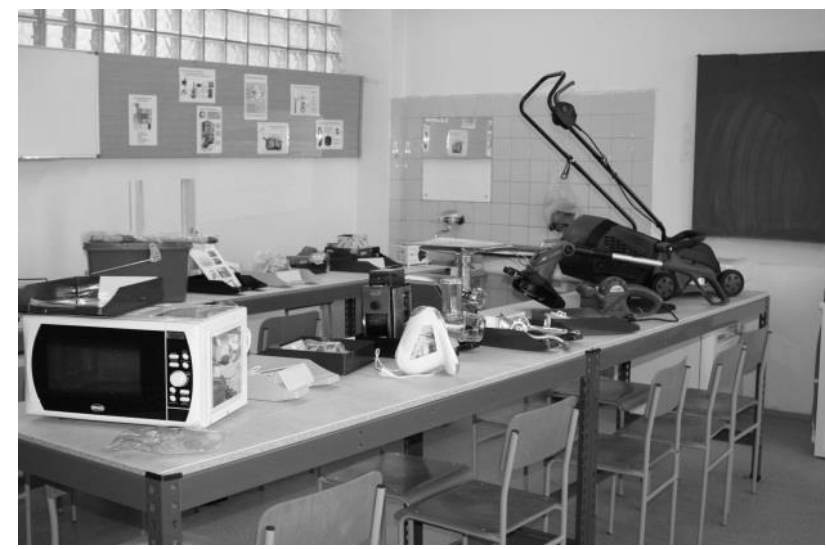

Obr. č. 2: Demonstrativni laboratoř odborných předmètů (CEPT, 2019).

Demonstrativní laboratoř je vybavena upravenými funkčními modely reálných strojů, přístrojů a zař́izení, se kterými žáci základních škol přicházejí do kontaktu v každodenním styku v domácnosti a v běžném životě (Pavelka \& Pavlenko, 2016). Poznávání principů, na základě kterých věci denní potřeby a jednoduchá technická zařízení fungují, je podpořeno jejich virtuálními modely a názornými funkčními simulacemi $(O b r . \check{c} .3)$, které jsou výsledkem řešení bakalářských a diplomových prací studentů FVT TUKE. 
Pracoviště pro strojní obrábění kovů, dřeva a plastů jsou vybavena strojním parkem pro technologie strojního obrábění kovů, dřeva a dalších technických materiálů. Umožňují dětem získat a dále zdokonalit nabyté praktické dovednosti a jejich tvưrčí aplikace využít při zpracování různých technických materiálů.

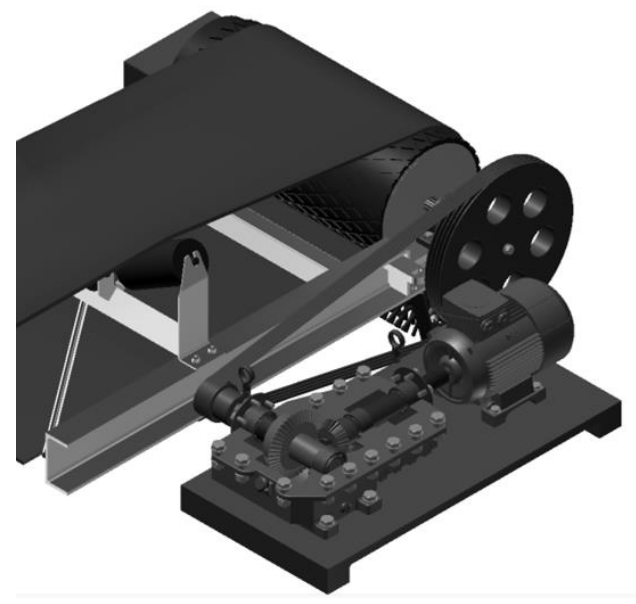

Obr. č. 3: Model pohonné stanice pásového dopravniku.

CEPT poskytuje své služby (výukové aktivity v netradičním didaktickém prostředí, exkurze a popularizační činnost, pilotní informace a návody pro ZŠ a učitele techniky, aj.) žákům i učitelům základních škol, studentům studujících učitelský studijní program technika a jejich pedagogům, dle zájmu i široké veřejnosti. Prostřednictvím web stránky mají žáci, učitelé techniky i veřejnost př́stup $\mathrm{k}$ souboru metodických materiálů vytvořených pro vzdělávací aktivity CEPT.

\section{Diskuse}

Jak tedy efektivně přistupovat $\mathrm{k}$ rozvoji technicky gramotné společnosti 21 . století? Nejlepší výsledky dosáhneme, pokud začneme s rozvojem technické gramotnosti už u nejmladší generace. Nejlepší výsledky dosáhneme, pokud se nám vzdělávacími a popularizačními aktivitami podaří povzbudit vnitřní motivaci dětí, která je postavena na přirozené zvědavosti a potřebě poznávat. Je vhodné navodit situaci, aby dětem zkoumání a objevování přinášelo nadšení, uspokojení, užitek, ale i naplnění jejich potřeb. Každého zajímají věci, které jsou nějakým způsobem důležité pro jeho život. Co je důležité pro děti - předškoláky, žáky prvního a druhého stupně základní školy? Musíme vycházet z toho, co děti znají, z jejich ambicí, očekávání, tužeb, otázek a problémů. Musíme jim ukázat, jaké to má propojení s tím, co jim prezentujeme.

Heslem při př́ípravě a realizaci výše uvedených popularizačních a vzdělávacích aktivit určených předškolákům a žákům základních škol byla otázka: „Jak věci funguji??“ Při společném hledání odpovědí se děti učily: 
- Jak a co na neznámých věcech pozorovat a popsat.

- Jak řešit problémy (hledání souvislosti příčiny a následku).

- Pracovat v týmu.

- Rozvíjet komunikační schopnosti.

- Sdílet a prosazovat vlastní myšlenky a nápady.

Vzbudit zájem a udržet pozornost dětí obecně je náročný úkol. Uvádím zde několik aspektů práce $\mathrm{s}$ dětmi, které bylo nutné respektovat ze strany přednášejících, pedagogů a animátorů:

- Děti věnují pozornost danému tématu obvykle 15 minut, maximálně půl hodiny. Pak se nudí a čekají něco nového. Výklad proto musí být poutavý a časově limitovaný.

- Dětem je třeba vždy dát prostor na otázky. K otázkám je třeba přistupovat velmi citlivě, žádnou otázku neznevažovat. Když, tak otázku pochválit a snažit se dětem srozumitelnou formou problém vysvětlit.

- Je třeba přihlížet na stupeň jejich znalostí (předškolní výchova, první a druhý stupeň základní školy).

- Děti jsou z různých domácích prostředí: rozdílná úroveň vzdělání rodičů, rozdílné sociální poměry, rozdílná komunita. Při práci s dětmi je nutné tyto rozdíly respektovat, zohlednit $\mathrm{v}$ komunikaci s jednotlivci, ale směrem $\mathrm{k}$ celému kolektivu dětí rozdíly potírat. Všechny děti mají stejná práva na vzdělání.

- Už při náznaku poklesu pozornosti je dobré přerušit výklad něčím zábavným, nebo prestávkou s pohybem.

- Zájem o prezentovanou problematiku, nebo činnost získat cílenými praktickými ukázkami. Například elektrický motor, magnet, spojené nádoby, teploměr, tlakoměr, různé hlavolamy; nebo možnost podívat se, co se to děje při provozu mlýnku, pračky, sekačky na trávu, vrtačky aj. pod krytem.

- Ríká se, že dnešní děti se rodí s mobilem v ruce. Tato věková skupina má extrémní zájem o výpočetní techniku, zejména hry. Tento zájem je tedy vhodné využít a děti usměrnit. Jsou tu široké možnosti modelování a simulace různých procesů na počítači, prohlížení zajímavých videí prezentujících zajímavé technické nápady a řešení, fungující zařízení, ukázky z technické praxe, například robotizovaná pracoviště aj.

\section{Závěr}

Volba povolání je jedním z nejdůležitějších a nejnáročnějších kroků v lidském životě. Výzkumy potvrzují, že profesní orientaci a volbu povolání žáků ve velké míře ovlivňují jejich rodiče (Hlad'o \& Drahoňovská, 2012; White, 2007). Výzkumy dále ukazují na okrajový vliv učitele v tomto rozhodování (Harris, 1992) a stále rostoucí vliv neformálního prostředí (Nuovo, 2003). Vzhledem k těmto skutečnostem hraje při př́ípravě žáků na volbu povolání klíčovou roli spolupráce všech složek společnosti. Nezbytná je spolupráce učitelů a odborníků ze základních, středních a vysokých škol, ale i profesionálů, vědců a techniků z praxe. Do popularizace vědy a techniky se musí aktivně zapojit i veřejné televize a média s plnou podporou vlády. Cílem je zvýšení zájmu žáků základních škol o techniku, rozvíjení technického myšlení, budování vztahu $\mathrm{k}$ technice a ke studiu oborů s technickým zaměřením. 
Poděkování: Příspěvek vznikl s podporou grantových projektů VEGA 080TUKE-4/2015 a APVV-18-0316.

\section{Literatura}

CEPT (2019). Centrum edukácie a popularizácie techniky. Dostupné z: https://www.unipo.sk/fakulta-humanitnych-prirodnych-vied/katedry/kfmt-fhpv/CEPT/.

Detská univerzita TUKE (2019). Dostupné z: https://detskauniverzita.tuke.sk/.

Dixon, R. A. (2013). Trends and Issues in Technology Education in the USA: Lessons for the Caribbean. Caribbean Curriculum. Vol. 21, 47-79.

Dostál, J., \& Prachagool, V. (2016). Technické vzdělávání na křižovatce - historie, současnost a perspektivy. Journal of Technology and Information Education. 8(2). pp. 5-24. DOI: $10.5507 /$ jtie.2016.006.

Harris, S. (1992). A Career on the Margins? The Position of Carreers Teachers in Schools. British Journal of Sociology of Education, 13(2), s. 163-176.

Hlad’o, P. \& Drahoňovská, P. (2012). Rozhodování žáků základních a středních škol o dalším studiu a práci v pohledu žáků i jejich rodičů. Praha: Národní ústav pro vzdělávání. Honzíková, J. \& Fadrnhonc, J. (2019). Aktivity a popularizační činnost v oblasti technického vzdělávaní v kontextu výběru oboru střední školy. Journal of Technology and Information Education. 11(1). pp. 28-37. DOI: 10.5507/jtie.2019.006.

Kmeč, M. (2017). Návrh a funkčná analýza wankelovho motora. Diplomová práca.

Kolektív autorov. (2015). Ako popularizovat vedu. Centrum vedecko-technických informácií SR, Dostupné z: https://www.cvtisr.sk/.

Kropáč, J. (2004). Technika, technické vědy, technická výchova. In Didaktika technických predmétů (vybrané kapitoly). Olomouc: UP.

NCP VaT - Národní centrum pro popularizaci vědy a techniky ve společnosti. (2019). Dostupné z: https://ncpvat.cvtisr.sk/

Pavelka, J. (2017). Activities of Education centers and popularization of technology of physics, mathematics and techniques of FHPV PU in the Prešov. Technika a vzdelávanie. 6(2).

Pavelka, J. \& Pavlenko, S. (2016). Podpora vzdelávania k technike a popularizácie techniky. In Technika a vzdelávanie. 5(2) pp. 6-8.

Stoffa, J. (1992). O všeobecnej technickej vzdelanosti mládeže. In: Technické vzdelávanie ako súčast' všeobecného vzdelávania. B. Bystrica: UMB, s. 30-33.

Stratégia slovenskej republiky pre mládež na roky 2014-2020. Dostupné z: https://www.minedu.sk/data/files/3889_strategia_pre_mladez.pdf

Šmeringaiová, A. \& Pavlenko, S. (2017). Implementácia CA - technológií do výučby. Príprava na budúcnost'. Trendy ve vzdělávání. 10(1). pp. 1-8. DOI: $10.5507 / \mathrm{tvv} .2017 .015$.

Špaček, V. (2015). Popularizace vědy v audiovizuálních médiích? Dostupné z: https://www.vyplnto.cz/realizovane-pruzkumy/popularizace-vedy-v-av/.

Turek, I. (2011). Globalizácia a jej vplyv na inováciu technického vzdelávania. Dostupné z: http://www.fhpv.unipo.sk.

White, P. (2007). Education and Career choice: A New Model Of Decision Making. New York: Palgrave Macmillan. 